\section{THE INFLUENGE OF} THE FIRST HUMAN

SPABE FLIBHII ON THE DEEIELOPMENII OF'RUSSIA AND THE HUMANIIIY

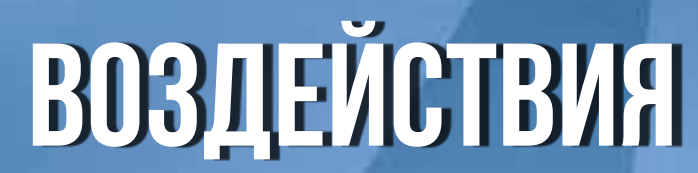
IEPBOГOIOJ㰯A पE्EIDBEKKA B KOBMOC HA PABBИTLE РOCEИИ ИЧЕЛОВЕЧЕСТВА

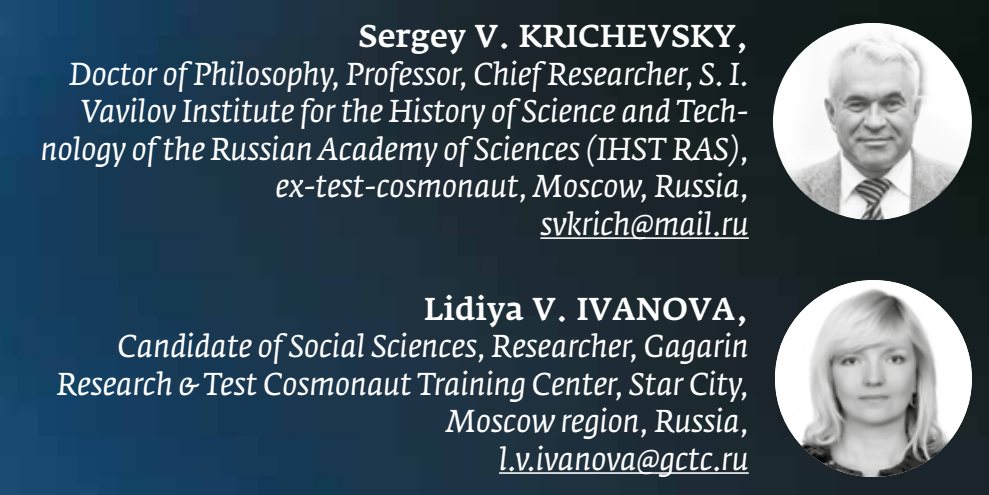

Сергей Владимирович КРИЧЕВСКиЙ, октор философских наук, профессор, главный научны отрудник Института истории естествознан экс-космонавт-испьтатапен, Москва, Россия, svkrich@mail.ru

Лидия Васильевна ИВАНОВА кандидат социологических наук, научный сотрудник НИИ «Центр подготовки космонавтов имени Ю. А. Гагарина», Звездный городок, Московская область, Россия, l.v.ivanova@gctc.ru
ABSTRACT I In connection with the 60th niversary of Yuri Gagarin's space flight, a brief interdisciplinary analysis concerning the influence of the flrst human space hum on the devisicis humanity is made. Scientific, technological, organizational and managerial, sociopolitical, socio-cultural, environmental, an futurological aspects are presented. The main conclusions are drawn. Keywords: influence, Gagarin, Earth, space, first flight, development, Russia, technology, man, humanity
АННОТАЦИЯ I В связи с 60-летием полет Ю. А. Гагарина сделан краткий междисциплинарный анализ основных аспектов комплекса воздействий первого полета человека в космос на развитие России и человечества. Представлены научный, технологический, организационный и управленческий, социально-политический, социокультурный, экологический, футурологический аспекты. Сформулиро ваны основные выводь. Ключевые слова: воздействие, Гагарин, Земля, космос, первый полет. развитие, Россия, технология, человек, человечество 


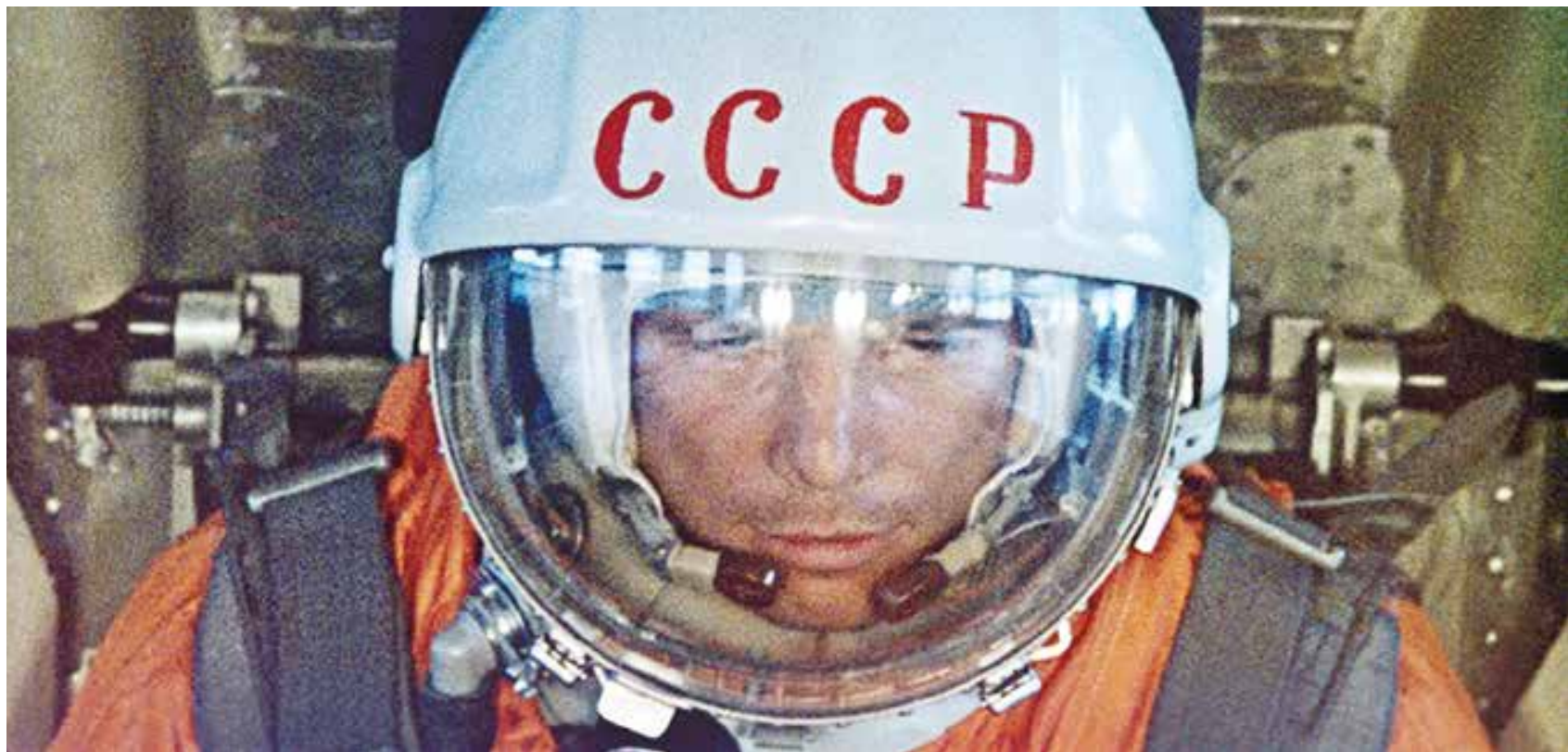

\section{ВВЕДЕНИЕ}

В связи с бо-летием полета Ю. А. Гагарина в космос сделаем краткий междиисиплинарвечество в контексте истории, настоящего и будущего.

К. Э. Циолковский за 40 лет до первого полета дал прогноз: описание полетов людей в космос (1920), а за 25 лет - облика и качеств первого космонавта (1935) [1, 2], во многом совпавшие с реалиями

После первого полета человека в космос вышли статьи с анализом его результатов и перспекти исследования иосвоения космоса. Одной из перыых была статья профессора В. В. Добронравов (1962): «Ю. А. Гагарин побывал там, где никогда еще не был ни один человек земли... Проникновет челове в восмос неизм еим раздвигаи культуру. Полет Ю. А. Гагарина показал, что путь человеку в межпланетное пространство к Луне, другим планетам в принципе открыт и требуется только время для дальнейшей отработки теоретических и практических вопросов. ...Трудно пока представить, как будет происходить дальнейшее освоение космоса. ...Но ясно одно: человечество не может остановиться в на-

В широком смысле следует и будем рассматривать не только сам полет длительность108 минуг от Старта до приземления первого исмонавта, но весь процесс его подтотовки
$\Delta$ Юрий Гагарин в корабле «Восток-1» Старт космического корабля «Восток» с пилотом-космонавтом Юрием Гагариным на борту У

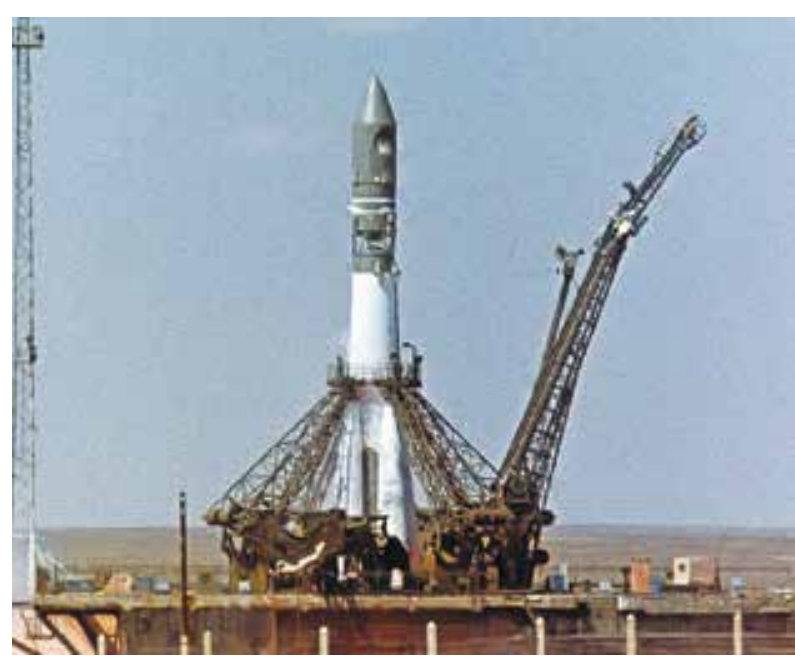

по его организации в 1959-1960 годах и включая ряд послеполетных технических и других дейстий и мероприятий после 12 апреля 1961 года (см.: [4-14]).

Пришло время подвести итоги 6о-летия и дат нию проблемы исследования и освоения космоса человеком в науке, образовании и практике. Рассмотим важные моменты основных аспеков воздействий первого полета человека в космос на развитие людей, нашей страны и мирового сообщества.
1. НАУЧНЫЙ И ТЕХНОЛОГИЧЕСКИЙ АСПЕКТЫ

Первый полет человека в космос является эталоном постановки и решения принципиально новой, сложнейшей научно-технической задачи в условиях чрезвычайно высоких уровней неопределенноси и риска при жестком дефиците времени и острой конкуренции за мирово лидерство.

В нашей стране были созданы основы ряда новых направлений в науке и технике. Исследованы возможности, особенности, ограничения техники и организма человека, получены новые знания для подготовки и выполнения пос применением новой ракетно-космической техники. Разработаны, созданы, испытаны мические технологии и техника для пилотируемых полетов. Отработаны и апробирован методики отбора и подготовки космонавтов, их профессиональной деятельности в космических полетах, обеспечения безопасности и выживания в штатных и нештатных ситуациях. В результате успешного полета Гагарина доказано, что человек может летать в космос, жить вне земли в условиях воздействия невесомости, друвозх фа.таров ка землю. Полет Гагарина дал новый импульс освоению космоса в мире и науч- но-технической космической гонке между СссР и США в 60-80 годах XX века. Важным этапом был первый выход человека в открытый космос (А. А. Леонов, СССР, 18.03.1965), кульминацией стала высадка первого человека на Луну (Н. Армстронг, США, 20.07.1969), затем последовало содание долговременных орбитальных станций. охруг земли на борту международн на орбите вокруг земли на борту Международной косми-

Первый полет человека в космос - это маяк и пример для развития национальной косми для участия новых стран в пилотируемых полетах, создания национальных пилотируемых программ, космической техники и технологий (в КНР, ЕС, Индии и др.).

Первый полет человека в космос является эталоном постановки и решения принципиаяьно новой,

спожнейщей научно-технической задачи в условиях чрезвычайно высоких уровней неопредеяенности и риска при жестком дефиците времени и острой конкуренции за мировое иидерство.

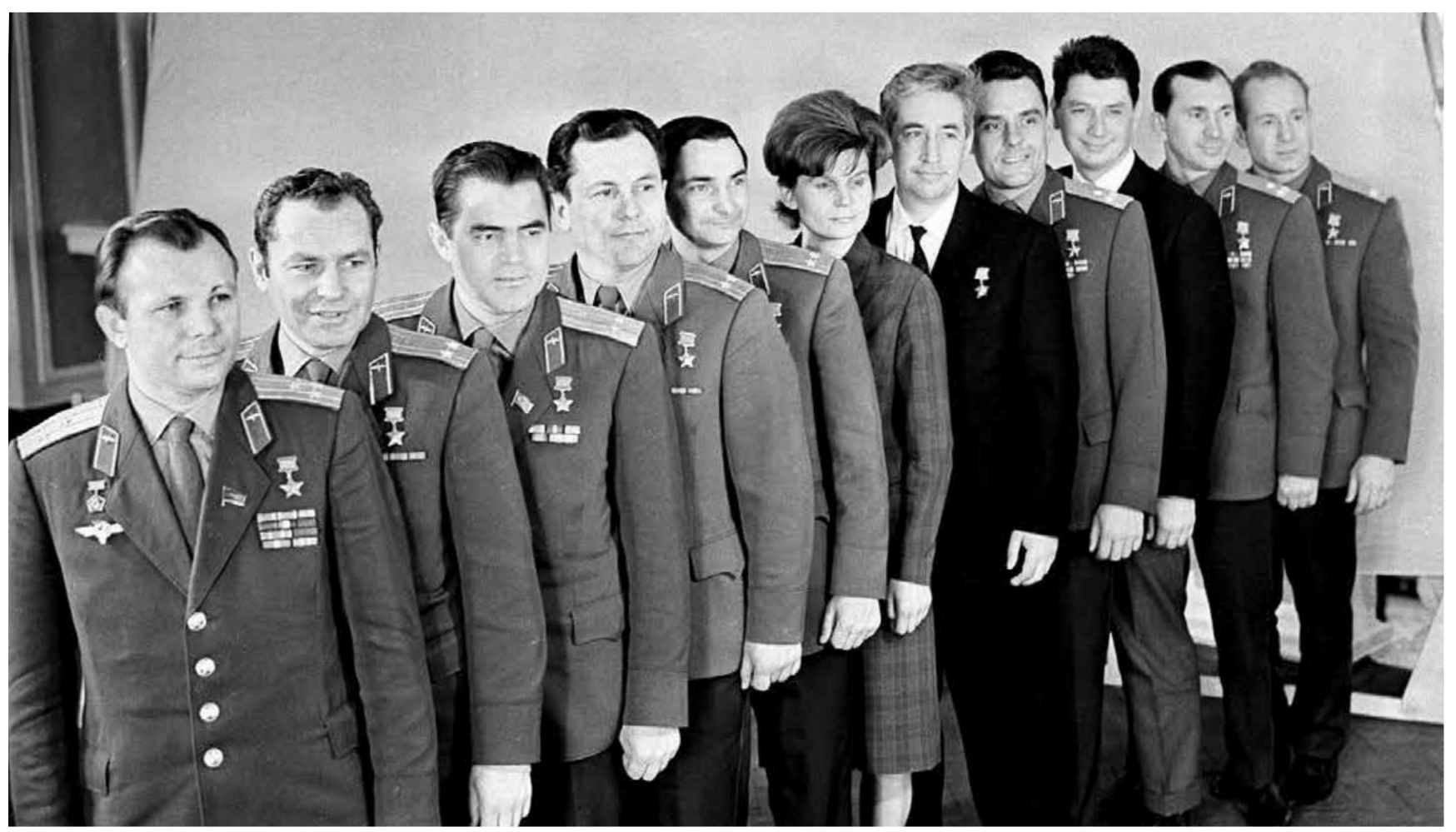

Фото первого отряда космонавтов СССР - первых 11, слетавших в космос 


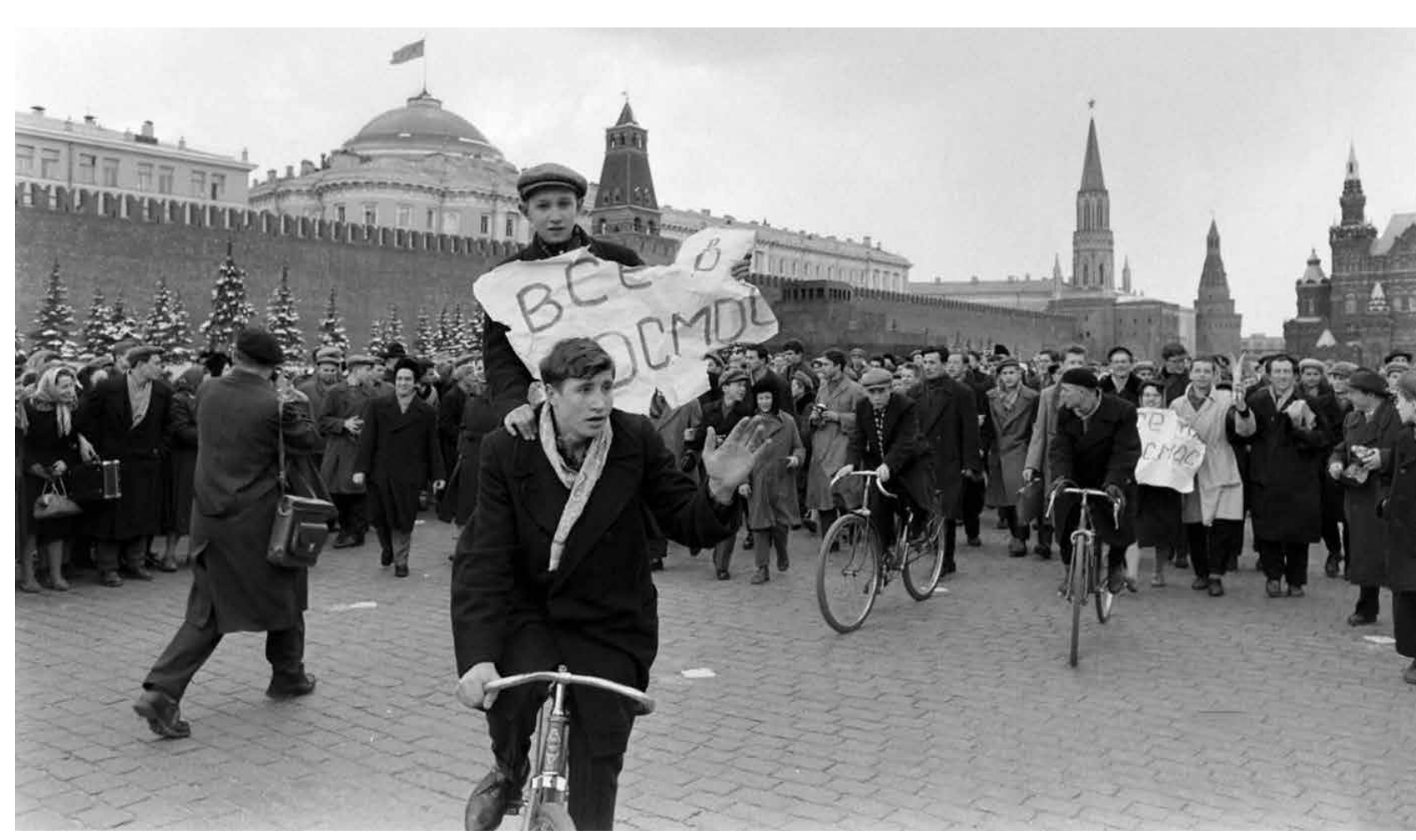

« «Все в космос!» - лозунг-призыв на стихийном митинге, состоявшемся после полета

Ю. А. Гагарина (Москва, Красная площадь, 12 апреля 1961 года)

\section{(2) ОРГАНИЗАЦИОННЫЙ И УПРАВЛЕНЧЕСКИЙ АСПЕКТЫ}

Первый полет человека стал основой пилотируемой космонавтики, в значительной мере повлиял на развитие всей космической отрасли, задал высокие требования и стандарты качества, надежности и безопасности космической техники и деятельноси. В СССР по инициативе ученых, инженеров, конструкторов под руководством органов власти, с участием Академи промы Мленности, образования, оранихаций созданы новые структуры и коллективы пюдей, в том числе системы управления, производства, испытаний, приобретен уникальный опыт организации пилотируемого космического полета и управления на полном жизненном цикле. выдающуюся роль в организации и выполнении первого полета человека в космос сыграл С. П. Королев. В 1960 году созданы Центр подготовки космонавтов и первый отряд космонавтов (2о человек). Многие специалисты, участвовавреализовали свой потенциал в космонавтике, пругих сферах управтения и практики, нако пили, формализовали, передали богатый опыт, оставили профессиональное наследие (документальное, кадровое, творческое). В России, США С, КНР и других странах регулярно проходя конкурсы по отбору космонавтов, за 60 лет в них и развивается сообшество космонавтов: профессиональные отряды космонавтов, астронавтов, международная Ассоциация участников космических полетов, объединяющая четыре национальные ассоциации. Полет Гагарина стал и остается главным примером и призывом для профессиональных космонавтов и новых кандидатов, мечтающих о полетах в космос и о работ в космической отрасли [5-17].

Первый полет человека стал основой пилотируемой космонавтики,

в значительной мере повлияя

на развитие всей космической отрасли, задая высокие требования и стандарты качества, надежности и безопасности космической техники и деятельности.

Выдающуюся роль в организации и выполнении первого полета человека в космос сыграл С. П. Королёв.
СОЦИАЛЬНО-ПОЛИТИЧЕСКИЙ АСПЕКТ

«Все в космос!» - таким был лозунг-призыв на стихийном митинге, состоявшемся после полета Ю.А. Гагарина в Москве на Красной площади 12 апреля 1961 года. Он отразил не только эйфорию праздника, настроени и мечты людеи в связи с выдающимся достижением и событием для СсСР и всего человече

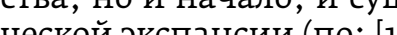

Международный и общемировой резонанс первого полета: человечество впервые ощутило ности четовека и нашей цивилиза возио ить космос с применением новых технологий и техники.

Первый полет установил критерий лидерства и "полноценности" космических государств, чалась и продолжается регистрация мировых рекордов людей в космосе.

В общественном мнении в России и мире выволщесте полета в космос является высшим профессиональным и личным достижением человека.

В честь пятидесятой годовщины полета чеповека в космос 7 апреля 2011 года резолючией A/RES/65/271 Генеральная ассамблея OOH провозгласила 12 апреля Международным днем полета человека в космос [18].

Полет в космос Ю. А. Гагарина считается в общественном сознании России и политике государства одной из главных скреп, высшим достижением сираны, науки и техники, символом нашего абсолютного приоритета и лидерства в освоении космоса.

Новая и парадоксальная реальность XXI века: в России в целом, и даже в космической отрасли, немало противников развития пилотируемой космонавнки, затраты на которую жета. По убеждениям множества людей, эффекта от нее якобы нет, а в стране сүшествует большое количество реальных и приоритетных земных социальных и других проблем, на решение которых не хватает средств. Например, в 2011 году появились крайне критические и по сути антикосмические призывы: "50 лет человек в космосе. Не пора ли обратно?» [19] Но как оценить полную социально-политическую цену и вклад полетов людей в космос, в том числе в категориях общественного блага, человеческого капитала и потенциала, в историю развития страны, в ее настоя

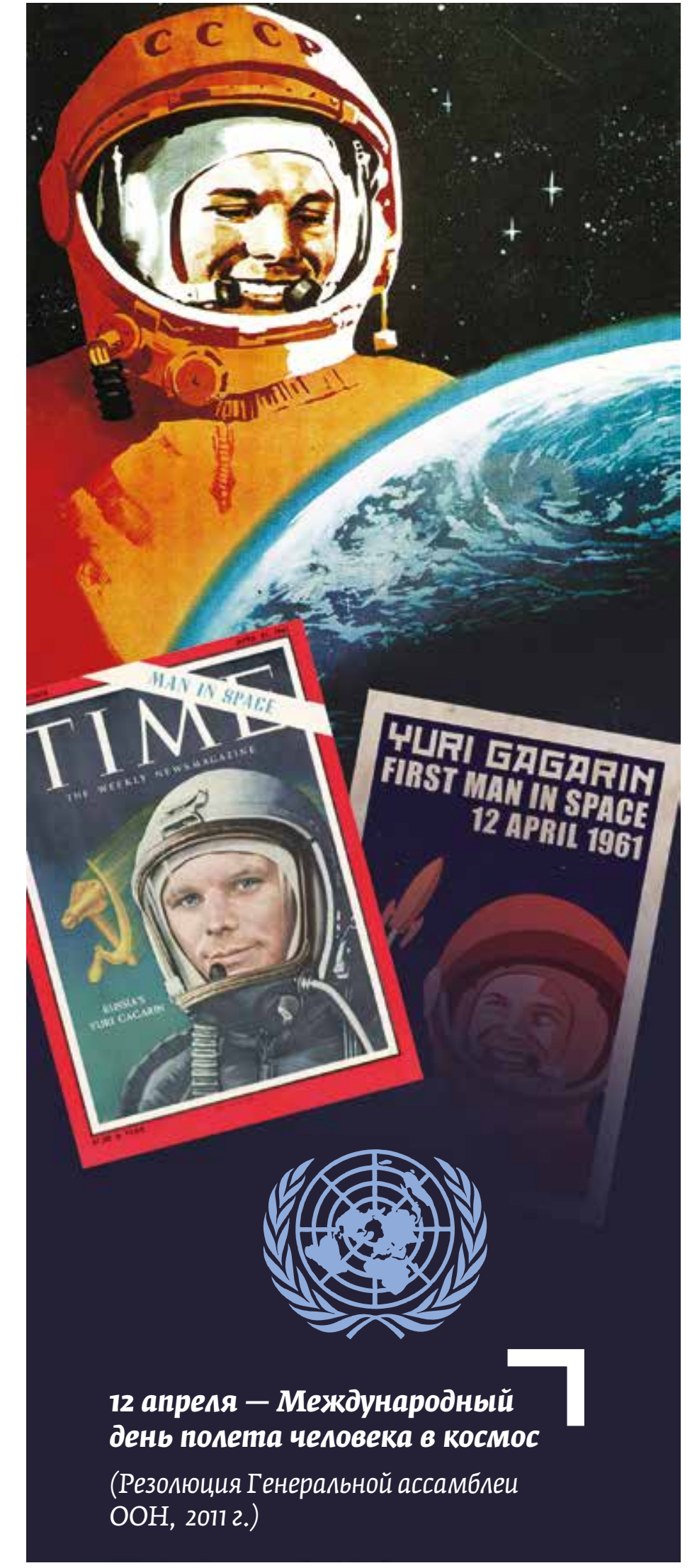




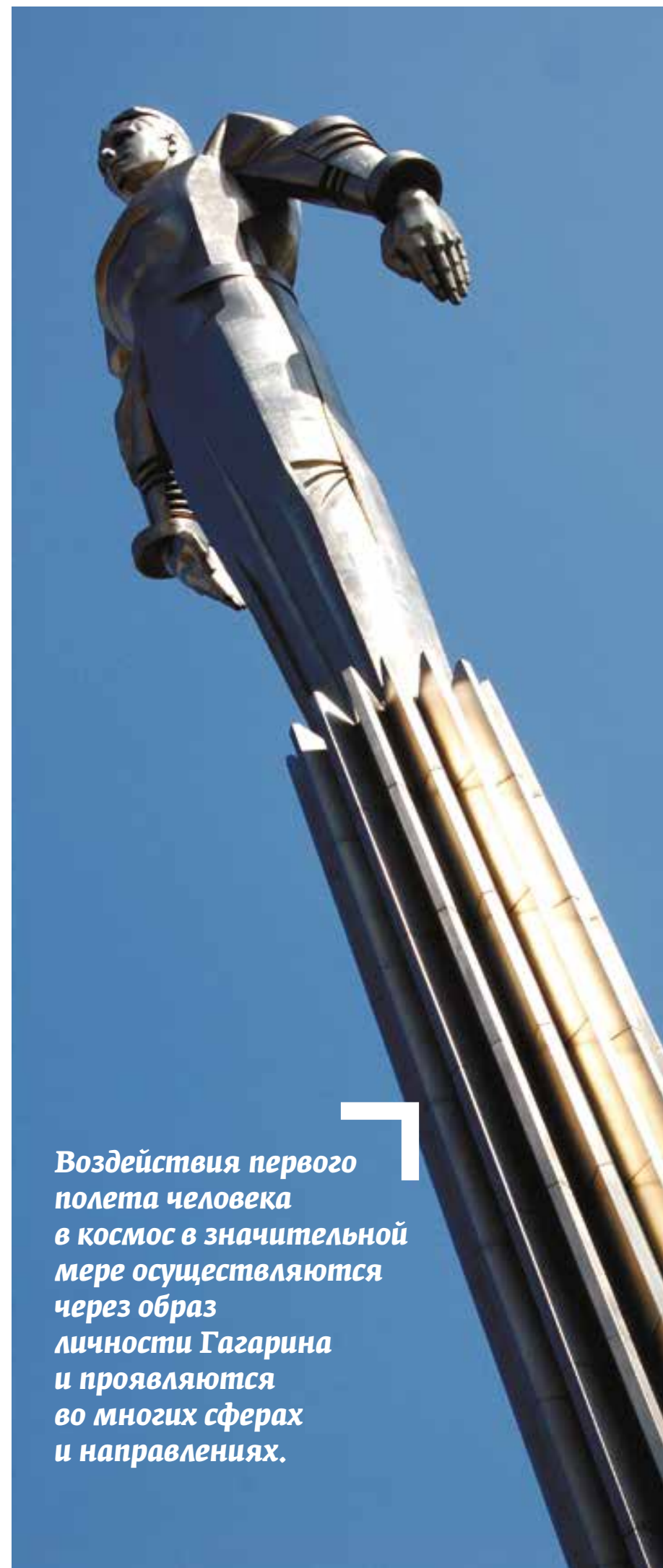

\Памятник Ю. А. Гагарину в Москве на площади Гагарина от полета Гагарина для страны и человечества? Как оценить научно-технологические, социокультурные и другие потери и последствия, если Россия откажется от полетов своих граждан в космос? По сути это запрет на космическую мечту, отказ от лидерства в космосе и экспансии.

Именно первый полет и образ Гагарина поддерживают в постсоветский период пилотируемую космонавтику В России, не дают остановить ее и разрушить. История, гордость за нее и стойвие для достойного космического будушего России и человечества: в пилотируемых полетах мы не имеем права делать ни шага назад и должны идти вперед. Необходимы новые цели, проекты, технологии, достижения.

Новыми лидерами процесса освоения космоса человеком с 2016 года в мире стали предприниматели, общественные деятели, новые корпорации и космические сообщества, которые конкуируют со «старыми" космическими соСе Среди них выделяются И. Маск, корпорация собех (США) и и. Р. Ашурбейли, космическое государство Asgardia (в нем участвует оволо 1 млн человек из -20о стран), для которых полет Ю. А. Гагарина явился и остается примером и импульСОМ для деятедьности и развития $[20,21]$.

\section{(4.) СОцИОКУЛЬТУРНЫЙ}

\section{ACחEKT}

Полет Гагарина, образ нашего героического соотечественника - первого космонавта мен XX века, одно из ярчайших событий всей отечественной и мировой истории, высших достижений человека, науки и техники.

Образ Ю. А. Гагарина - одна из основ космической субкультуры, он постоянно отражается и воспроизводится в общественной и культурной жизни нашей страны и мира, во всем информационном пространстве, в СМИ и современных элекронных сетях

Первый полет человека в космос в индивидуальном и общественном сознании остается подвигом и абсолютным рекордом человека, продолжение: первый выход человека в отқрытый космос, первый шаг на Луне, предстоящий первый шаг на Марсе.

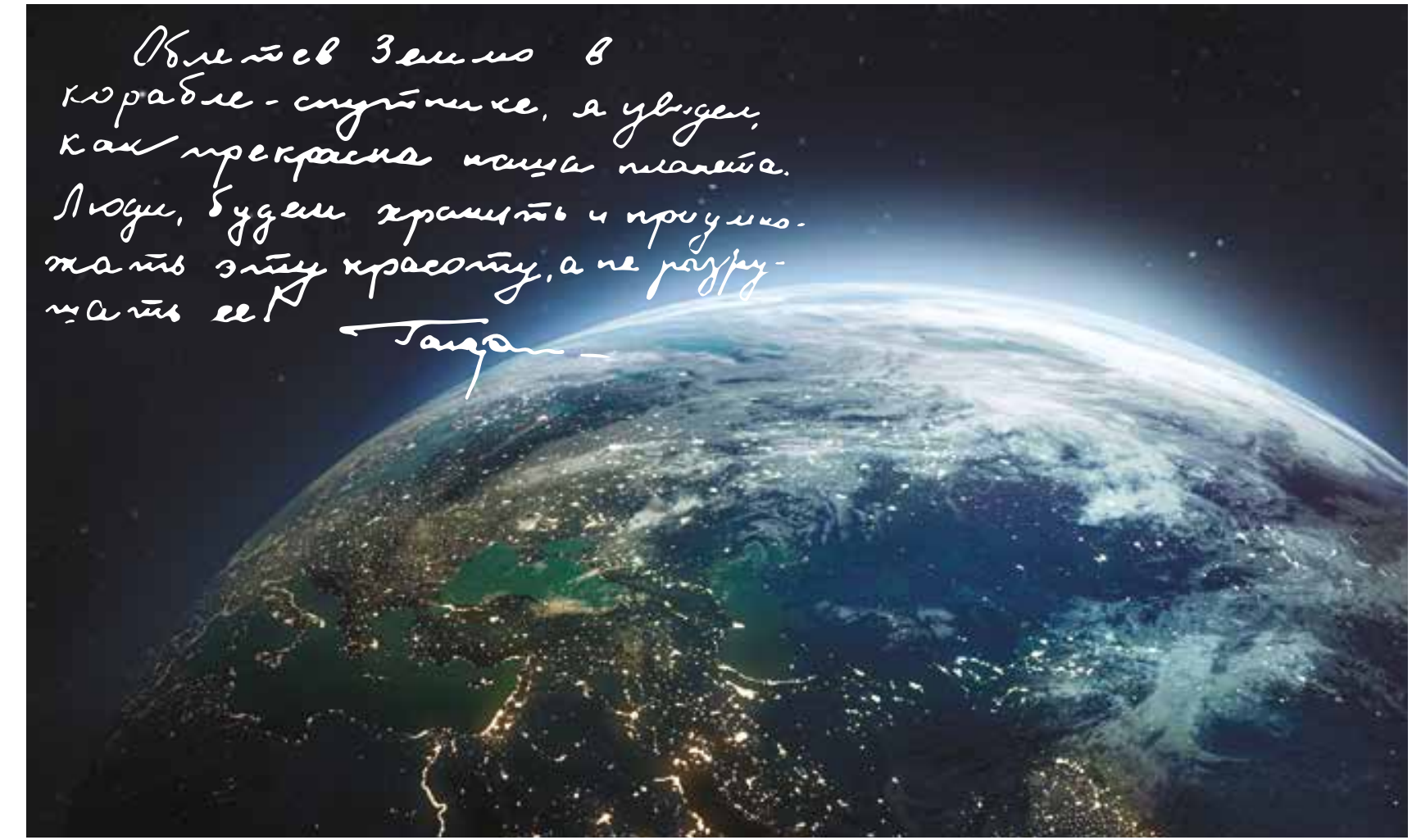

« «Экологическая» записка Ю. А. Гагарина, написанная после полета (копия автографа), и вид Земли из космоса

Воздействия первого полета человека в космос значительной мере осуществляются через образ личности Гагарина и проявляются во многих сферах и направлениях. Прежде всего в науке, образовании, литературе и искусстве, в том числе в масштабных социокультурных проектах: в создании памятников, музеев, выставок, кинофильмов, музыкальных и других произведении; в работе планетариев, космоцентров; в проведении космических форумов, конференции, чтений, космических уроков, спортивных состязаний и т. д. Невозможно пии, нумизматики, бмблематики, фалеристики и др. (см.: [6-12, 14]). Подвиг Гагарина имеет особое значение для дежи, определения нели жизни гак пример стремления к освоению новых знаний и технологий, самореализации и достижения успеха в сложной профессии, активной деятельности в интересах страны и всего человечества. Воздействия первого полета человека проявляются в процессе создания, институционализации и деятельности новых космических сообщест в России и мире (см.: $[14,21])$.

\section{(3) ЭКОЛОГИЧЕСКИЙ}

\section{ACחEKT}

Своим первым космическим полетом и взглядом в космос и из космоса на Землю Ю. А. Гагарин открыл, ощутил и дал нам новое "очеи космое» измерение и понимание Земли пространства «зежаюей среды как единот ну мира, нашего желаемого и возможнного будущего с приоритетом сохранения, сбережения людьми родной планеты. После полета он написал об этом в короткой и эмоциональной "экологической» записке: “Облетев Землю в ко рабле-спутнике, я увидел, как прекрасна наша тлу красоту а не разрушать

Вслед за Гагариным более 560 человек в мире побывали в космосе, и каждый ощутил красоту монавтов, а также из других источников многие земляне узнали об окружающей среде и природных ресурсах Земли и космоса, о нарастании экологических проблем и загрязнений. Это имеет большое значение для формирования экологического сознания людей и экологизации всей деятельности человечества. 


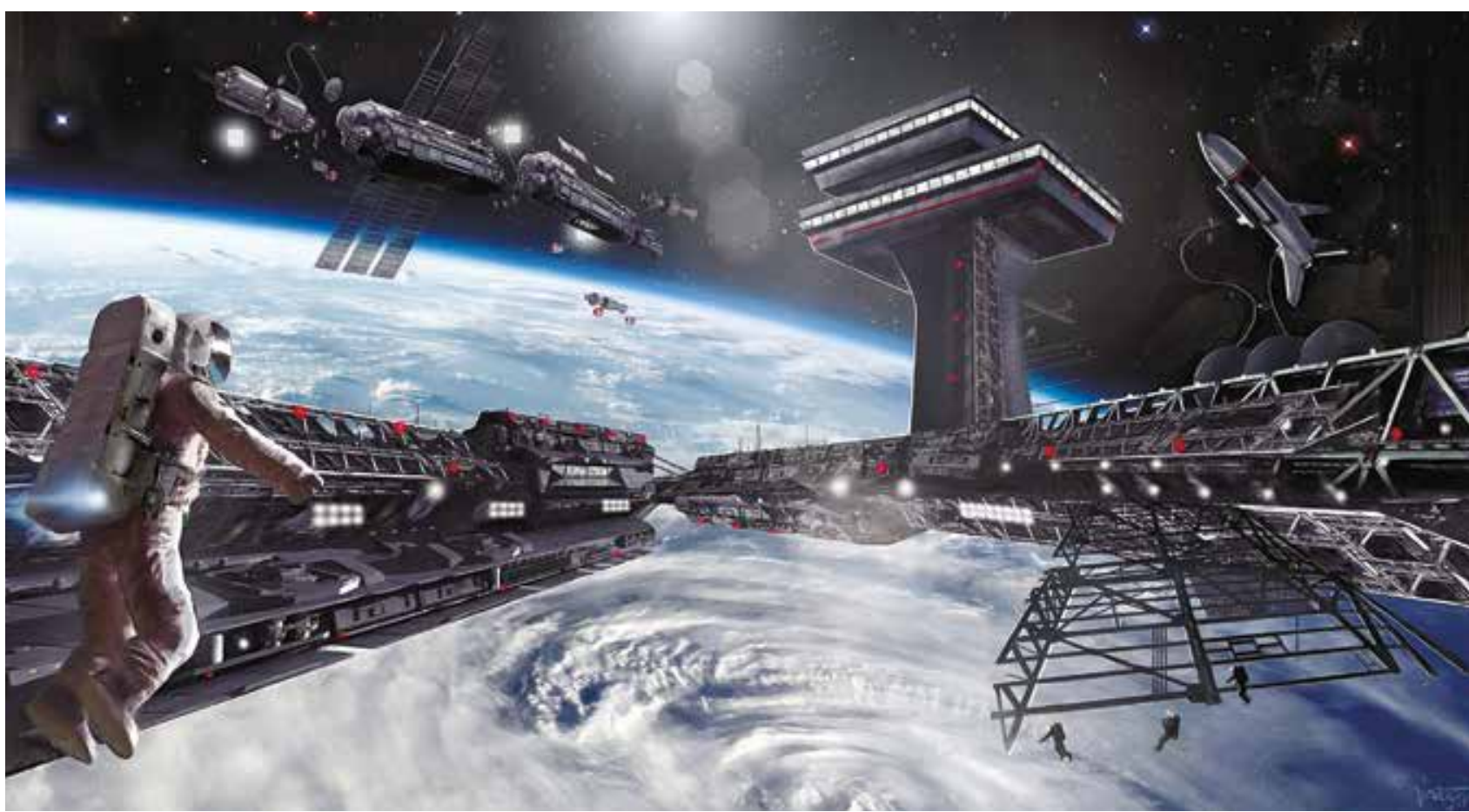

Образ будущего (визуализация космической инфраструктуры)

(6) ФУТУРОЛОГИЧЕСКИЙ ACחEKT

Полет Гагарина символизирует вектор развития человека и человечества, наше земное и косжение в космос с сохранением ведүщей роли, статуса и свойств человека.

В мире в 10-20-е годы XXI века началась и поднимается новая водна освоения космоса человеком и человечеством с применением новых технологий и техники, включая роботов ка помощников и др. Идет процесс индустриализации космической деятельности в целях реше ния проблем на Земле, добычи и использования внеземных ресурсов, освоения Луны и Марса. На повестке дня возвращение человека на Луну, пасоянная база и начало колонизации Лун ве - искусственная гравитация и вашита от радиации для людей в космосе; пилотируема экспедиция на Марс и его колонизачия; создание условий для репродукции - рождения и постоянной жизни людей вне Земли; создание космического человека и человечества, многопланетной человеческой цивилизации. Все это требует качественно нового продолжения процесса освоения космоса человеком: выхода за ограничения и достигнуые пределы полетов и жизни людей в космосе, учета и парирования новых рисков, организации международного повечества» (см.: [15-17, 20, 21]).

\section{ОСНОВНЫЕ ВЫВОДЫ}

1. Первый полет человека в космос оказал мощное воздействие на СССР/ Россию, все мирово сообщество, продолжает влиять на общественное сознание, развитие науки и техники, космической и других сфер деятельности как важный пример возмо сностей человека, общества, государ и аосмической экстансии.

2. Главным актором процесса освоения космоса был, является и будет человек, стремящийся циал, ограничения и перспективы теловека в космических полетах, организации безопасной и достойной постоянной жизни вне Земли должны быть приоритетом новых исследований, технологий, образования и практики.

3. Необходимо переосмысление истории, опыта и результатов освоения космоса человеком для коррекции целей, разработки новой стратегии, программ, проектов и технологий космической деятельности в балансе с решением проблем на Земле в интересах России и человеуества на новом этапе космической эры.
Первый полет человека в космос оказал мощное воздействце

на СССР и Россию, все мuposoe сообщество, продолжает вииять на общественное сознание,

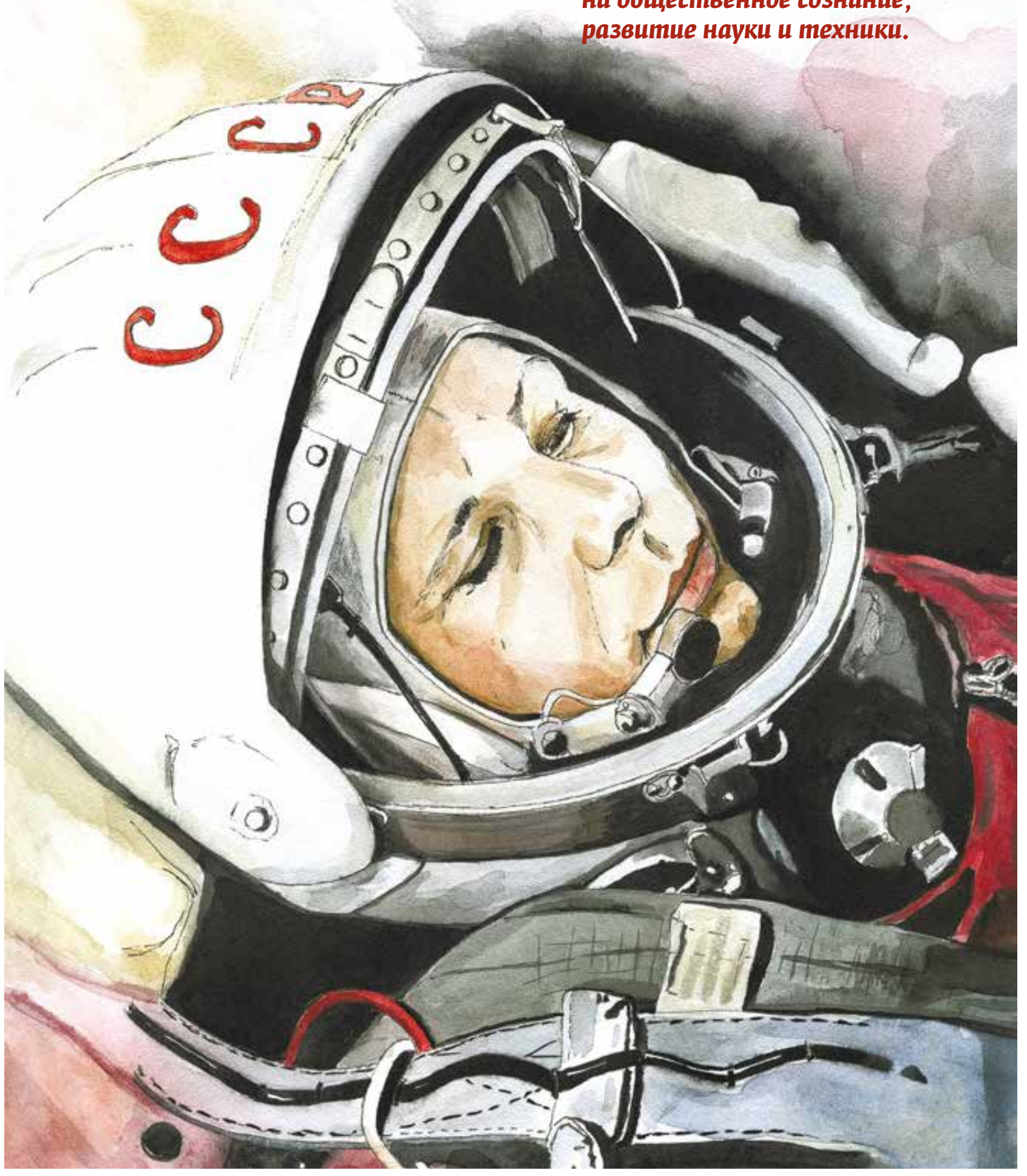




\section{Литература}

. Циолковский К.Э. Вне Земли. Повесть. калуга: Изд-во Калужского общества изучения природы и местного края, 1920

2. Бурцева Н.Л. Нострадамус космоса: $\mathrm{k}$ С. С. $8-15$.

С. Добронравов В.В. Что дал первый космонавтика. 1962. № 4. С. $10-19$. URL: https://epizodsspace.airbase.ru/bibl/al-k/1962/chto-dal.html (Дата обращени

4. «Облетев Землю, я увидел, как прересурс] // Газета. Вu. 2016. 16 апреия URL:: https:/ / www gazeta ru/science/photo/ obletev_zemlyu_ya_uvidel_kak_prekrasna nasha_planeta.shtml (Дата обращения: 14.01.2021).

5. Советская космическая инициатива в осударственных документах. 1946-1964 гг. / Под ред. Ю. М. Батурина. М.: РТСоф miposan

. ка. История. Техника. Люди / Под ред.
Ю. М. Батурина. М.: РТСофт, 2005.752 с 7. Каманин н.п. Скрытый космос: в 4 нн. М. Инфортекст-ИФ, оОО ИИД Новости косм. М. тики, 1995, 1997, 1999, 2001. 1 кн. - 400 с. 2 кн. - 448 с.; 3 кн. - 352 с.; 4 кн. - $384 \mathrm{c}$
8. Госкорпорация «Роскосмос» (Россия) [Электронный ресурc]. URL: https:// 14.01.2021).

9. Ракетно-космическая корпорация (Электром имени С. П. Королева (Россия) energia.ru/ (Дата обращения: 14.01.2021) 10. ФГБУ «НИИ ЦПК им. Ю. А. Гагарина» (Россия) [Электронный ресурс] URL: http://www.gctc.ru/ (Дата обращения: 14.01.2021).

1. Космическая энциклопедия ASTROno [электронный ресурс]. URL: http:// astronaut.ru/index.htm (Дата обращения:

12. Объединенный мемориальный музей (2) 14.01.2021).

13. Леонов А.А. Время первых. Судьба моя я сам. М: АCT, 2019. 352 c.

Ж6ество космонавтов. История стано ления и развития за полвека. Проблемы. Перспекий / педисл. В.П. Савиных. М

5. NASA (США) [Электронный ресурс].

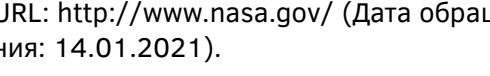

16. Пора присоединить Луну к Земле.

на XXIV Планетарном конгрессе участнкико космических полетов 5 сентября 2011 года
[Электронный ресурс] // Новая газета. 2011.23 сентя6pя. URL: https://novayagazeta. 14.01 2021) -

17. Кричевский С.В. «Космический» опыт, перспективы // воздушек-косми ческая сфера. 2020. № 1. С. 26 - 35. DOI. 18. 18. ООН. Международный день полета челй ресурс] URL: - https;//www [электронobservances/human-spaceflight-day/ru/ обращения: 28.01.2021).

19. Сурдин В.Г. 50 лет человек в косморесурс] // Полит.ру. 2012. 13 апреля. URL: https:///polit.ru/article/2012/04/13/space surdin/ (Дата обращения. 09.01.2021). 20. SpaceX (США) [Электронный ресурс]. URL: http.// /www.spacex.com (Дата обраще

[Электро Asgardia - The Space Nation asgardia.space/ (Дата обращения: 14.01.2021).

\section{References}

K.E. Vne Zemli. Povest'.

Kaluga, Izdatel'stvo Kaluzhskogo

obshchestva izuchen
kraya, $1920.118 \mathrm{p}$.

2. Burtseva N.L. Nostradamus kosmosa:

.

p. $8-15$.

3. Dobronravov V.V. Chto dal pervyy

kosmonavtika., 1962, no. 4, pp. 10 - 1

Available at: https:///epizodsspace.airbase ru/bibl/a-i-k/ 1962/chto-dal.html (Retrieva date: 14.01 .2021 .

4. "Obletev Zemlyu, ya uvidel, kak prekrasn nasha planeta." Gazeta.ru. 2016. Aprill 16. photo/obletev zemlyu ya uvidel kak prekrasna_nasha_planeta.shtml (Retrieval date: 14.01 .2021 ).

5 . Sovetskaya kosmicheskaya initsiativa $v$ gosudarstvennykh dokumentakh. 19461964 gg. Ed. Yu. M. Baturin. Moscow, RTS (2008. $416 \mathrm{p}$

6. Mirovaya pilotiruemaya kosmonavtika. Moscow, RTSoft, 2005. 752 p. M. Baturin.

7. Kamartekst-IF, 000 IDD Novosti kos. Moscow, vol. 1, 1995, $400 \mathrm{p}$, vol. 2, 1997, $448 \mathrm{p}$. vol. 3, 1999, 352 p., vol. 4, 2001, 384 p.
8. Goskorporatsiya "Roskosmos" (Russia). (Retrieval date: 14.01.2021).

9. Raketno-kosmicheskaya korporatsiya "Energiya" imeni S. P. Koroleva (Russia). (Retrieval date: 14.01.2021).

10. FGBU "NII TsPK im. Yu. A. Gagarina"

(Russia). Available at: http//www gctcru/ (Retrieval date: 14.01.2021).

11. Kosmicheskaya entsiklopediya

ASTROnote. Available at: http://astronaut.

u/index.htm (Retrieval date: 14.01.202

2. Ob"edinennyy memorial'nyy muzey

va. A. Gagarina. Available at: https://

13. Leonov A.A. Vremya pervykh. Sud'ba - ya sam. Moscow, AST, 2019. 352 14. Ivanova L.V., Krichevskiy S.V.

tanovleniya i razvitiya za polveka. Pro Perspektivy. Moscow, LIBROKOM, 2013. $200 \mathrm{p}$

5. NASA (USA). Available at: http://www. nasa.gov/ (Retrieval date: 14.01.2021). 16. Pora prisoedinit' Lunu k Zemle. Vystuplenie akademika RAN B. E. Chertoka na XXIV Planetarnom kongresse uchastniko Kosmicheskikh poletov 5 sentyabrya 2011 Available Novaya gazeta. 2011. September 23 articles/2011/09/23/46013-pora- prisoedinit-lunu-k-zemle (Retrieval date: 14.01.2021)

17. Kricheuskiy S.V. "Kosmicheskiy" chelovek: idei, tekhnologii, proekty, opyt, sfera, 2020 , no 1 , pp. 26 - 35 . DOI: 10.30981/2587- 7992-2020-102-1-26-35 18. O0N. Mezhdunarodnyy den' poleta cheloveka v kosmos - 12 aprelya. Available at: https://www.un.org/ru/observances/ 28.01.2021)

19. Surdin V.G. 50 let chelovek v kosmose. Ne pora li obratno? Polit.ru. 2012. April 13. Avallable at. https.///polit.ru/ (Retrieval date: 09.01.2021).

20. SpaceX (USA). Available at: http:// www.spacex.com (Retrieval date 14.01.2021).

- The Space Nation. Available 14.01.2021). 